\title{
Nanotechnology in Oncology
}

\author{
Srujana Joga ${ }^{1} \quad$ V. P.B. Koyyala ${ }^{2}$ \\ ${ }^{1}$ Department of Medical Oncology, Rajiv Gandhi Cancer Institute \\ and Research Centre, New Delhi, India \\ ${ }^{2}$ Department of Medical Oncology, Homi Bhabha Cancer Hospital \\ and Research Centre, Visakhapatnam, Andhra Pradesh, India \\ Ind J Med Paediatr Oncol 2021;42:93-95.
}

Address for correspondence Srujana Joga, DNB (General Medicine), Department of Medical Oncology, Rajiv Gandhi Cancer Institute and Research Centre, New Delhi, India (e-mail: srujanajoga@gmail.).

a positive charge at infusion so that they target blood vessels immediately after infusion, and they can be made to switch to neutral charge after entering the tissues allowing faster diffusion into tumor tissues.

5. Solubility, degradation, and clearance: Hydrophilic nanoparticles improve water solubility, prevent degradation and clearance by the reticuloendothelial system, thereby increasing the stability and bioavailability of the drug. The application of polyethylene glycol over nanoparticles achieves this property of hydrophilicity.

6. Targeting: The main advantage in the nanoparticlemediated drug-delivery systems is the release of drug after reaching the target. This can be achieved through three different mechanisms ${ }^{3}$ :

i. Active targeting: By ligand (on nanoparticle)-receptor (on tumor cell surface) binding.

ii. Passive targeting: Accumulation of Nab-paclitaxel in pancreatic tumor tissue is a typical example of this mechanism where enhanced permeability and retention effect are achieved because of the neoangiogenesis in tumor tissues with leaky blood vessels.

iii. Triggered release: This can be achieved by release systems operating upon specific stimulus or trigger acting at the target site. This trigger can be internal in the tissue like changes in $\mathrm{pH}$ compared with intravascular space, differences in the redox potential of tissues, changes in charges and ionic strength, etc. In specific conditions, external stimuli can be used to mediate drug or chemical release from the nanoparticle. Some technologies are using physical stimuli like hyperthermia to dislodge drug in a particular tissue and also the infrared and ultraviolet wavelength of light for the release of drugs in superficial tissues such as skin and subcutaneous tissues.
DOI https://doi.org/ $10.1055 / \mathrm{s}-0041-1729727$ ISSN 0971-5851
(C) 2021. Indian Society of Medical and Paediatric Oncology This is an open access article published by Thieme under the terms of the Creative Commons Attribution-NonDerivative-NonCommercial-License, permitting copying and reproduction so long as the original work is given appropriate credit. Contents may not be used for commercial purposes, or adapted, remixed, transformed or built upon. (https://creativecommons.org/licenses/by-nc-nd/4.0/). Thieme Medical and Scientific Publishers Pvt. Ltd. A-12, 2nd Floor, Sector 2, Noida-201301 UP, India 


\section{Types of Nanoparticles}

1. Organic substances like proteins, lipids, protein-lipid polymers, liposomal particles, and gelatins such as hydrogels are commonly used.

2. Inorganic substances like silica, hafnium oxide, gold, magnetic particles.

3. Drug conjugates with antibodies.

4. Viral nanoparticles.

\section{Applications of Nanotechnology in Oncology}

Coming to the uses of nanoparticles in oncology, they are used extensively in diagnostic applications, therapeutic purposes, and a combination of both referred to as theranostic applications (- Table $\mathbf{1}$ ). ${ }^{4}$

\section{Diagnostic}

Nanoparticles have large surface area to volume ratio, due to which they can be densely covered with antibodies, small molecules, peptides, aptamers, and other moieties. These moieties can bind and recognize specific cancer molecules. Quantum dots, gold nanoparticles, and polymer dots are three common nanoparticle probes used in diagnosing cancer.

\section{Detection of Biomarkers}

- A zinc oxide quantum dot-based immunoassay was developed for the detection of carcinoembryonic antigen in predicting tumor recurrence after the completion of colorectal cancer treatment.

- Gold nanoparticles for the detection of human epidermal growth factor receptor 2 in breast cancer.

- Various nanoparticles are used to detect DNA, RNA, miRNA sequences, methylation of histone proteins, and extracellular vesicles.

\section{Detection of Cancer Cells}

Circulating tumor cells (CTCs) are already approved by the US Food and Drug Administration for prognostication in some cancers such as colorectal, breast, and prostate cancers. However, it is difficult to isolate CTCs in earlier stage due to their small number. Nanoparticles help in capturing and isolating CTCs by targeting some tumor-specific proteins among billions of cells, literally picking a needle in a haystack, for

Table 1 Applications of nanotechnology

\begin{tabular}{|l|l|l|}
\hline Diagnostic & Therapeutic & Theranostic \\
\hline $\begin{array}{l}\text { 1. Detection of } \\
\text { biomarker }\end{array}$ & $\begin{array}{l}\text { 1. Targeted drug } \\
\text { delivery }\end{array}$ & $\begin{array}{l}\text { For both diagnostic } \\
\text { and therapeutic } \\
\text { purpose }\end{array}$ \\
\hline $\begin{array}{c}\text { 2. Detection of } \\
\text { cancer cells }\end{array}$ & $\begin{array}{l}\text { 2. Overcoming } \\
\text { multidrug } \\
\text { resistance }\end{array}$ & \\
\hline $\begin{array}{c}\text { 3. In vivo tumor } \\
\text { imaging }\end{array}$ & & \\
\hline
\end{tabular}

example, detection of epithelial cell adhesion molecule using magnetic nanoparticles.

\section{In Vivo Imaging}

Nanoparticle probes preferentially accumulate in tumor tissues through active or positive targeting, thereby a very useful tool in radiodiagnosis. ${ }^{5}$ Ongoing clinical trials with nanotechnology-based applications in cancer diagnosis are listed below:

- Carbon nanoparticles as lymph node tracer in rectal cancer after neoadjuvant radiochemotherapy.

- Silica-hybrid nanoparticles for positron emission tomography imaging of patients with metastatic melanoma or malignant brain tumors.

- Nanoparticles are being evaluated as specific "immunosensors" to detect DNA, RNA, miRNA sequences, methylation of histone proteins, and extracellular vesicles.

\section{Therapeutic}

\section{Targeted Drug Delivery}

The main therapeutic application is to increase the efficacy and decrease the toxicity of conventional chemotherapeutic agents by targeted delivery. Some of the commonly used drugs are mentioned in - Table 2 .

Table 2 Nanomedicines in oncology

\begin{tabular}{|l|l|}
\hline Type of nanoparticle & Active drug \\
\hline Liposome & Doxorubicin, cytarabine \\
\hline Liposome (PEGylated) & Doxorubicin, irinotecan \\
\hline Liposome (Non-PEGylated) & $\begin{array}{l}\text { Daunorubicin, vincristine, } \\
\text { mifamurtide }\end{array}$ \\
\hline Nanoparticle albumin bound & Paclitaxel \\
\hline PEG protein conjugate & L-Asparaginase \\
\hline PEG-PLA polymeric micelle & Paclitaxel \\
\hline
\end{tabular}

Abbreviation: PEG-PLA, polyethylene glycol-polylactide.

Table 3 Advantages and disadvantages of nanotechnology

\begin{tabular}{|l|l|}
\hline Advantages & Disadvantages \\
\hline $\begin{array}{l}\text { Increased solubility of } \\
\text { highly lipophilic drugs }\end{array}$ & $\begin{array}{l}\text { Lack of proper knowledge about } \\
\text { the effect of nanoparticles on bio- } \\
\text { chemical pathways and processes } \\
\text { in human body }\end{array}$ \\
\hline $\begin{array}{l}\text { Tunable physical and } \\
\text { chemical properties }\end{array}$ & $\begin{array}{l}\text { Unpredictable genotoxicity due to } \\
\text { insufficient toxicological assess- } \\
\text { ment studies }\end{array}$ \\
\hline $\begin{array}{l}\text { Targeted drug delivery } \\
\text { and controllable manner }\end{array}$ & $\begin{array}{l}\text { Elimination and metabolism vary } \\
\text { with different types of materials } \\
\text { used in nanoparticle synthesis }\end{array}$ \\
\hline $\begin{array}{l}\text { Good biocompatibil- } \\
\text { ity, bioavailability, and } \\
\text { biodegradability }\end{array}$ & More expensive \\
\hline $\begin{array}{l}\text { Decreased toxicity or side } \\
\text { effects of drugs }\end{array}$ & Short shelf life \\
\hline
\end{tabular}




\section{Overcoming Multidrug Resistance}

Of the many mechanisms of drug resistance in chemotherapeutic agents, one of the most important and common mechanism is the overexpression of P-glycoprotein (p-gp) over tumor tissues, which mediates the drug efflux and so-called multidrug resistance (MDR). Nanoparticles can help overcome this in the following ways: (i) Simultaneous delivery of the drug to tumors and inhibition of the MDR proteins. (ii) Partially bypassing the efflux pump as they are internalized by endocytosis; (iii) Downregulating the expression of p-gp using siRNA.

\section{Abscopal Effect}

Radiotherapy-activated hafnium oxide nanoparticles kill more cancer cells than radiotherapy alone in distant tumors due to increased CD8+ lymphocyte T-cell infiltrates-an abscopal effect.

\section{Theranostics}

Nanoparticles are to play a major role in personalized medicine by their application in the branch of theranostics where drugs are used simultaneously to diagnose and treat the medical conditions.

As with every new innovation, there are pros and cons ${ }^{6}$ for nanotechnology also as listed in - Table 3.

\section{Financial Support and Sponsorship}

Nil.

\section{Conflicts of Interest}

There are no conflicts of interest.

\section{References}

1 Wicki A, Witzigmann D, Balasubramanian V, Huwyler J. Nanomedicine in cancer therapy: challenges, opportunities, and clinical applications. J Control Release 2015;200:138-157

2 Zhang Y, Li M, Gao X, Chen Y, Liu T. Nanotechnology in cancer diagnosis: progress, challenges and opportunities. J Hematol Oncol 2019;12(1):137

3 Tran S, DeGiovanni PJ, Piel B, Rai P. Cancer nanomedicine: a review of recent success in drug delivery. Clin Transl Med 2017;6(1):44

4 Pillai G, Nanotechnology toward treating cancer: A comprehensive review. In: Applications of Targeted Nano Drugs and Delivery Systems. Cambridge, USA: Elsevier; 2019 221-256

5 Bhandare N, Narayana A. Applications of nanotechnology in cancer: a literature review of imaging and treatment. J Nucl Med Radiat Ther 2014;5:195

6 Benefits of Nanotechnology for Cancer-National Cancer Institute, Division of Cancer Treatment and Diagnosis. Available from: https://www.cancer.gov/nano/cancer-nanotechnology/benefits. Accessed April 16, 2021 